\title{
Prof dr FJ van Zyl se Skrifbeskouing
}

\author{
PA Geyser \\ Pretoria
}

\begin{abstract}
Prof Dr FJ van Zyl's view on Scripture
\end{abstract}

In this article an endeavour is made to depict a representive picture of Professor Van Zyl's many articles about his view on Scripture. As a theologian of the Reformed tradition he was one of a very selected few who articulated a theological reflection about Scripture. Moving from Karl Barth's viewpoint, he developed his own ideas while also paving the way for historical criticism and other modern methods of research into the understanding of the Bible as such.

\section{INLEIDING}

Die een teoloog in die geledere van die Nederduitsch Hervormde Kerk wat hom op deurlopende basis besig gehou het met die formulering van 'n Skrifbeskouing is prof dr FJ van Zyl. Dit blyk reeds wanneer 'n mens kyk na 'n artikelreeks wat in die jare 1944 - 1945 in Die Hervormer verskyn het. Dit was 'n samevatting en verwerking van 'n lesing voor die predikantevergadering oor 'Die Skrifbeskouing van Karl Barth' wat in die HTS, Aflewering 3, 1944 verskyn het. Dit is opgevolg met 'n reeks artikels gedurende 1969 en 1970 in Die Hervormer onder die opskrif 'Ken jy die Bybel?' en het uitgeloop het op 'n publikasie Die Boek van alle boeke. Maar nie net oor hierdie langerige tydspan van by die dertig jaar waarin die ontwikkeling en die deurdinking van die Reformatoriese teoloog FJ van Zyl duidelik blyk nie, maar ook na my oordeel soos wat die implikasies van sy Skrifbeskouing in sy hele teologiebeoefening na vore gekom het.

In sy lesings, artikels, bydraes wat mondeling of skriftelik voor die Kerk gedien het, maar veral ook in sy prediking het hierdie uitgekristaliseerde Skrifbeskouing telkens na vore gekom. Die volledige lys van publikasies is aangedui in die artikel van PJ van der Merwe in hierdie selfde uitgawe van die HTS, daarom sal telkens slegs na 'n publikasie by die naam verwys word in hierdie artikel. Verder wil ek in hierdie artikel poog om Van Zyl self aan die woord te stel oor die kwessie van 
Skrifbeskouing. Hier en daar sal enkele opmerkings as kantlynkritiek wel figureer, maar oor die algemeen sal dit aan die leser oorgelaat word om selfstandig 'n oordeel te vorm oor die deurdagtheid, die gerypdheid van Van Zyl se denke oor hierdie saak en om self uit te maak in watter groot mate dit baanbrekerswerk was. Na my oordeel is hierdie werk van Van Zyl vir die Nederduitsch Hervormde Kerk van onskatbare waarde, nie omdat dit soseer die vorming van denke oor Skrifbeskouing behels het nie, maar veral omdat dit die verwoording van ongeskrewe en ongeformuleerde teologiese uitgangspunte bevat wat in die wyse van teologiebeoefening in die Hervormde Kerk baie sterk funksioneer tot op ons dag.

Soos die aanduiding van die toespraak voor die predikantevergadering reeds aandui, naamlik 'Die Skrifbeskouing van Karl Barth', is daar seker 'n mate van reg in die uitspraak van ds Joh Dreyer in die voorwoord van Die Boek van alle boeke dat die Skrifbeskouing van FJ van Zyl in 'n baie groot mate gevoed en gevorm is deur die Skrifbeskouing van Karl Barth. Ek meen tog dat Van der Merwe gelyk gegee kan word dat Van Zyl se eie Skrifbeskouing in daardie artikelreeks en veral ook in die opvolg artikelreeks uit die jare 1969-1970 duidelik blyk en wel as die vrug van deurleefde nadenke in die lig van resente navorsing en standpunte. Hoe dit ook al sy, Van Zyl is in elk geval die teoloog wat via die denke van Barth grondliggende werk gedoen het op hierdie terrein van die Nederduitsch Hervormde Kerk se nadenke oor Skrifbeskouing.

\section{DIE BOEK VAN ALIE BOEKE}

As uitgangspunt vir Van Zyl se nadenke kan sonder gevaar van teëspraak gestel word dat hy die Bybel as die Boek van alle boeke beskou het. As teoloog in hierdie Reformatoriese tradisie het hy die plek van die Bybel op grond van die Reformatoriese spreuk Sola Scriptura konsekwent as uitgangspunt gehandhaaf. Daarmee saam het hy ook as kerklike teoloog, as mens wat sy toelogiebeoefening altyd in diens van die kerk gestel het, ook die betekenis van die Bybel vir die persoonlike geloofslewe en van 'n hele lewe op Bybelse grondslag na vore gebring:

Een van die geseëndste vrugte van die Kerkhervorming vir die Christengelowige is seker die voorreg om die Woord van God in eie taal en in eie huis te kan lees. Voor die Hervorming was daar ook reeds Bybels in die volkstaal, maar dit is eers met die Hervorming dat die Bybellees deur enkelinge so 'n vername plek ingeneem het. Ons moet dit verklaar uit die begeerte van die Hervormers om die hele lewe op Bybelse grondslag op te bou, en die nadruk wat hulle op 
persoonlike geloofslewe en op die algemene priesterskap van die gelowiges gelê het (Die Hervormer, April 1944).

Hoewel daar dus groot klem geplaas word op die belangrikheid van die lees van die Bybel, word die vraag oor waarom die Bybel gelees word ook duidelik in perspektief geplaas, naamlik omdat dit die Boek is waardeur God Hom aan die mens openbaar.

Ons lees die Bybel omdat ons daarin die sprekende stem van God verneem. Daarom het die Bybel gesag, daarom is hy die norm, die maatstaf van ons hele lewe.

In sy verwerking van hierdie standpunt tree die balans ook baie duidelik na vore wanneer die Bybel as boek behandel word. In sy artikels is daarmee die weg gebaan om die Bybel nog as godsdienstige objektiewe voorwerp nog as magiese middel te hanteer. Daar word uitgegaan van die werklikheid dat ons in die Bybel met 'n boek (inderdaad ook as 'n boekery) te doen het.

'n Mens sou ook kon begin deur iets baie indrukwekkenders, iets baie meer verhewe, baie meer diepsinnig van die Bybel te sê as dat hy 'n boek is. Ter geleënertyd sal al daardie diepsinnige, verhewe en indrukwekkende dinge van die Bybel ook gesê moet word. Maar dis nodig dat hierdie eenvoudige en skynbaar onbelangrike van die Bybel ook gesê word: dat hy 'n boek is. Wat in hom geskrywe staan, is uniek, is enig en kan in geen ander boek ter wêreld gelees word nie, maar wat sy uiterlike vorm, sy gestalte betref wil hy nederig sy plek inneem onder al die boeke van die wêreld, wil hy saam met hulle op die tafel lê en in die boekrak staan. Soos enige ander boek word hy vandag gedruk.

Dis nie net die uiterlike vorm nie, maar ook die geskrewe inhoud van hierdie boek wat so deur en deur aan die menslikheid van die Bybel herinner: dis mense wat hom geskrywe het in die taal en die idioom van hulle tyd. Nou haas ons ons om te sê, dat Jesus van Nasaret die Seun van God was, en dat die Bybel meer as 'n menslike boek is. Wat in Hom geskrywe is, is nie net mensewoorde nie, maar dis tegelyk ook die Woord van God. Maar aan die ander kant het ons die Godswoord weer nie los van die mensewoord nie, en daarom moet ons die gewone boek-karakter van die Bybel nie van minder belang ag nie (Die Henormer, April 1944). 
In die verdiskontering van hierdie werklikheid dat die Bybel 'n boek is, gaan Van Zyl ook nie by die grondvraag verby nie, naamlik waar kom hierdie boek vandaan, hoe is hy saamgestel, in watter opsig het dit as 'n produk van manuskripte vir ons tot boek geword. Daarom word die hele kwessie van tekskritiek en die plek van tekskritiek in Van Zyl se Skrifbeskouing nie verbygegaan nie. Die probleme rondom tekskritiek word duidelik uitgewys en tog kom Van Zyl tot die gevolgtrekking dat die betroubaarheid en die waarheid van die Bybel op 'n ander vlak lê as in die onfeilbaarheid van die woorde en die letters wat in hierdie boeke opgeteken is. Iets van sy grondliggende beskouing blyk hierin wanneer hy stel:

Hierdie boek is alleen waar en hy word vir ons 'n boek van betekenis as die lewende Heer van Wie hy getuig deur hierdie getuienis met ons begin praat van Homself. Die boek is dus nie die eerste nie, maar die Heer. Hy is die waarheid. Hy is die handelende, Hy maak Homself bekend. Ons sou dit ook anders kon sê: omdat die Drie-enige God die subjek van die Openbaring is, omdat dit $\mathrm{Hy}$ is wat die waarheid is en oor die waarheid beskik, daarom is ' $n$ onfeilbare boek, daarom is literêre foutloosheid nie voorwaarde vir geloofssekerheid nie. Nooit mag die kerk verflou om so noukeurig as moontlik die oorspronklike teks van die Bybel te probeer vasstel nie, want God het ons aan hierdie Boek gebind om Hom te ken. Nooit mag ons egter ook twyfel aan die betroubaarheid van die Bybel nie, ondanks die feit dat die oorspronklike teks verlore gegaan het en daar enkele menslike foute by die afskrifte kon ingesluip het nie. Omdat God die handelende by die Openbaring van die waarheid is, is Hy nie aan 'n foutlose boek gebonde nie. Hy is groter as die Bybel en kan Hom bekendmaak sonder die Bybel, maar daarom juis kan $\mathrm{Hy}$ hierdie Boek waaraan $\mathrm{Hy}$ ons gebind het in sy menslike feilbaarheid gebruik om kenbaar en hoorbaar tot ons te spreek (Die Henormer, April 1944).

Oor die Kanon-vraag het Van Zyl hom in 'n groot mate vereenselwig met die standpunt van Barth oor hierdie aangeleentheid. Dit kom in kort daarop neer dat die Ou en Nuwe Testament soos ons dit in sy geheel het die kanon is. Ook die vraag waarom juis die geskrifte wat saamgevat is in die Ou en Nuwe Testament, as reël van die waarheid, as Kanon van die kerk gestel is, le die antwoord eenvoudig omdat die Bybel hom tot Kanon maak. Hy is Kanon omdat hy hom as sodanig op die kerk geimponeer het. Die Bybel is Kanon omdat hy dit is. Hiermee saam word dus gestel die erkenning van die Bybel as Kanon in en saam met die kerk en dit beteken 
dit is die kerk wat hierdie skrif as Heilige Skrif gevind het en as sodanig erken het. Die kritiese vraag kom na vore in die vereenselwiging met hierdie standpunt.

Die vasstelling van die kanon staan vir Barth dan ook gelyk aan die vasstelling van 'n dogma, in die betreklikheid van 'n menslike erkenning van die waarheid deur God aan die mens geopenbaar. Hy wys op die lang geskiedenis wat agter die vaslegging van die kanon lê, en geraak dan tot die slotsom dat ons moet toegee dat die konkrete gestalte van die kanon geen absolute, maar net 'n hoogs relatiewe afgeslotenheid kan wees (Die Hervormer, April 1944).

In hierdie beskouing vind ons iets weerspieël van wat die Nederduitsch Hervormde Kerk ook in sy gesprekke by die Tussenkerklike Kommissie so geformuleer het: 'Die kanon is vir ons de facto geslote maar de jure wel oop.' Tog het Van Zyl baie sterk uitgegaan van die genoegsaamheid van die Kanon as Openbaringsgetuienis om God te ken en om die saligheid te kan beërwe.

\section{MENSLIKE GETUIENIS VAN DIE OPENBARING}

Van Zyl het homself duidelik ook gevind in die opvatting van Barth dat die Bybel en die Openbaring van God nie in 'n een tot een verhouding met mekaar staan nie. Die Bybel is altyd die menslike getuienis van die Openbaring. In die mate waarin die Bybel vir ons die toegang tot die Openbaring is, is dit ook Woord van God. Maar ons het hierdie Woord van God nie anders as in die menslike woorde van die Bybelgetuienis nie. Getuig beteken in hierdie verband om in 'n bepaalde rigting bokant, op 'n ander heen te wys. Die getuienis van die Bybelskrywers is altyd 'n verwysing na die Andere. Ons kan die Woord van God alleen vind in hierdie vorm van die getuienis van mense aangaande die Openbaring.

Die Woord van God ontmoet ons in hierdie vorm en afgesien daarvan is daar vir ons geen Woord van God nie. Ons kan by die vraag na die Openbaring ons nie van die teks losmaak nie. Maar, en daarop juis laat Barth alle klem val, die menslike bly hier menslik, sonder om goddelik te word. Daar bestaan geen persoonseenheid tussen God en die menslikheid van die Profete en Apostels nie. As Woord van God in die teken van hierdie profeties-apostoliese mensewoord, is die Heilige Skrif nie net goddelik, en ewemin net menslik, en ewemin 'n menging tussen God en mens. Maar hy is op sy wyse en sy trap soos 
Jesus Christus self: ware God en ware mens, d.i. getuienis van die Openbaring wat self tot die Openbaring behoort, en 'n historiese litereare dokument van 'n bepaalde mensheid (Die Hervormer, April 1944).

Van Zyl lewer ook kritiek op Barth se opvatting oor die onafgeslotenheid van die Kanon.

Barth se opvatting van die onafgeslotenheid van die kanon, stel ons nie tevrede nie. O.i. moet die kanon vanuit Pinkster gesien en verstaan word. Met die uitstorting van die Heilige Gees gaan gepaard die aanname van die Outestamentiese Skrif as gesaghebbende getuienis van Jesus Christus (vgl. die rede van Petrus, in Hand. 2). Die Heilige Gees sluit Hom dadelik aan by die skriftelikheid van die Woord, sodat ons nie net van die inkarnasie, vleeswording, van die ewige Logos moet spreek nie, maar ook van 'n inskripturasie, skrifwording van die Logos, die Logos van die Heilige Gees. Die Heilige Gees is die Gees van Profete en Apostels, die Gees waardeur hulle gespreek het. Soos die eenmaligheid van die vleeswording en noodwendige afsluiting van die Outestamentiese kanon beteken, so lê in die eenmaligheid van die gebeurtenis van die Geesuitstorting die fondament en grond vir die afgeslotenheid van die hele Bybelse kanon (Die Hervormer, April 1944).

Oor hierdie opvatting van Van Zyl en ook ander in verband met die Kanon sal daar in die debat wel enkele vrae en punte van kritiek oorbly. So byvoorbeeld die stelling:

Die Nuwe Testament veronderstel die geldigheid van die Ou Testament. Met die vasstelling van die Nuwetestamentiese kanon word die Ou Testament ook as kanon erken.

Veral gesien teen die agtergrond van sy eie stelling: 'Teen die einde van die eerste eeu na Christus en teen die einde van die vierde eeu is die boeke van die Ou en Nuwe Testament respektiewelik vasgestel as kanon'. Maar ons sal nie in hierdie artikel in die debat oor die Kanonkwessie verder wou ingaan nie. 


\section{DIE VERHOUDING TUSSEN MENSEWOORD EN DIE WOORD VAN GOD}

Om terug te keer na die meer sentrale aspekte van Van Zyl se Skrifbeskouings kan nog die volgende opgemerk word. Wanneer hy stel dat dit dus duidelik is dat ons in die Bybel die menslike getuienis vind van die Woord van God, of anders gesê dat die Bybel die getuienis van die Openbaring van God bevat, is die bedoeling baie duidelik nie om die Bybel as Woord van God te ondergradeer nie. Trouens dit word baie sterk gestel. Die Bybel is eerstens nie ' $n$ boek wat woorde oor God bevat nie, maar as Woord van God is die Bybel God self in sy Woord. In hierdie baie belangrike aspek oor wat die verhouding is tussen die woorde van die Bybel en die Woord van God kom ook die plek en die funksie van die Heilige Gees baie duidelik na vore.

Ons kan die twee nie met mekaar gelykstel nie. Die mensewoorde van die Bybel is nie op hulleself die Woord van God nie, maar bly mensewoorde deur en deur. As die Bybel as Heilige Skrif erken wil word, moet daar iets gebeur; dan moet ons in hierdie mensewoorde meer as net mensewoorde verneem; moet ons nie net Jesaja of Jeremia of Paulus hoor nie, maar moet ons in en deur hulle woorde die sprekende stem van God self hoor. Eers wanneer dit gebeur word die mensewoorde vir ons God se Woord, word die Bybel vir ons boek van die openbaring. Eers wanneer God die mensewoord van die Bybel in Sy diens neem om vir ons daardeur te sê wat Hy wil sề, eers dan hoor ons die Bybel as Woord van God tot ons spreek. Eintlik kan ons nie sè dat die Bybel die Woord van God is nie, want hy moet vir ons altyd weer opnuut die Woord van God word, waar en wanneer dit God behaag om ons deur die Bybelwoord aan te spreek. Hierdie gebeurtenis waardeur die mensewoord van die Skrif vir ons Woord van God word, vind plaas deur die getuienis van die Heilige Gees. God bewerk 'n wonder deur Sy Gees, naamlik dat ons nie mensewoorde hoor wanneer ons die woorde van die Bybel hoor nie, maar Sy eie Woord (Die Hervormer, April 1944).

\section{DIE ONTMOETINGSASPEK VAN DIE WOORD}

Die een saak wat in Van Zyl se teologie oor die Woord baie duidelik na vore kom en wat telkens weer op 'n vars wyse verdiskonteer word, is wat ook via Brunner bekend kan wees as waarheid as ontmoeting, die ontmoeting met 'n Persoon of wat 
ook in meer onlangse debat bekend geword het as 'n relasionele waarheidsbegrip. Wie in die Woord van God, God self hoor en wie in die Woord in aanraking kom met die wesenlike van die Openbaring, naamlik die persoon Jesus Christus, word ook geroep tot 'n persoonlike verhouding met hierdie persoonlike God en daarom ook die besondere klem wat geloof in die Skrifbeskouing van Van Zyl kry.

Dit gaan in die hoor van die Woord van God wesenlik om die ontmoeting met die lewende God in die Seun van Sy liefde deur die wonderwerking van die Heilige Gees. As die Bybel vir ons die Woord van God word, beteken dit eintlik dat die Heilige Gees vir ons die deur van hierdie menslike getuienis oopmaak sodat Christus uit hierdie getuienis ons tegemoet tree. Die skepping van die wêreld uit niks is ' $n$ ontsaglike wonder. ' $n$ Wonder is die vleeswording van die ewige Seun van God, 'n wonder Sy opstanding uit die ontslapenes. Nie minder groot is die wonder wanneer die Bybel as die boek wat ons met al sy menslikhede leer ken het vir ons die Woord van God word (Die Henormer, April 1944).

Daar is seker reeds tot op groot hoogte geillustreer dat Van Zyl die gesag van die Woord nie gesoek het in bepaalde opvattings oor onfeilbaarheid, foutloosheid, waarheid in die sin van objektiewe gegewens wat geverifieer kan word nie. Hy het die beskouing oor die Bybel ook bevry van elke poging om daarin wetenskaplike gegewens oor elke ander denkbare terrein van die lewenswerklikheid te bekom.

Daarom moet ons ook nie in die Bybel iets anders gaan soek nie. Dis nie 'n boek vir geologie, biologie en psigologie nie. Dit wil ons geen chronologie, geografie of wêreldbeskouing aanbied nie. Daar is ander boeke in die wêreld wat ons hieroor kan inlig. In die Bybel staan slegs die dinge geskrywe wat ons kan help om God in ons lewe te eer en om self tot die saligheid te kom. Die Bybel gebruik een kernwoord waarin die eer van God sowel as die saligheid van die mens betrek word, naamlik geloof. As God se openbaring tuiskom by 'n mens, ontstaan daar deur die werking van die Gees geloof. Dis 'n baie veelsinnige woord hierdie wat ook vertroue, gehoorsaamheid, eerbied en diens insluit (Die Henormer, April 1944).

Met dit alles het Van Zyl gestaan in die tradisie van die Dialektiese teologie wat ook deur sommiges as die Neo-Ortodoksie beskrywe word (Barr, Hasel e a). In sy 
nadenke oor die Skrif en deur sy geskrifte het Van Zyl dus ook die weg gebaan vir refleksie oor die Bybel en dit het ook die deure geopen om die Bybel as literatuur te bestudeer. Daarmee saam het die histories-kritiese metodes ook 'n staanplek deur sy nadenke gevind. Elke moontlike sleutel moes benut word om die boodskap van die Bybel te kan verneem. Omdat die uitgangspunt geld dat die Bybelskrywers telkens bokant hulleself uitwys na die saak waardeur hulle in beweging gebring is, na die Persoon wat in hulle lewens ingegryp het en wat hulle hart en verstand opgeëis het sodat hulle nie anders kon as om in Hom te glo, op Hom te vertrou, om Hom lief te hê en aangaande Hom te getuig nie.

\section{SAMEVATTING}

Aangesien Van Zyl uitvoerig gepubliseer het oor die onderwerp van Skrifbeskouing kon daar uit die aard van die saak slegs eksemplaries enkele grepe uit sy denkwêreld hier aangebied word. Hopelik is daar geillustreer dat hy op hierdie terrein 'n wesenlike bydrae gelewer het. Hoewel daar sommige aspekte van sy formulering mag wees waaroor daar verskille bestaan of al sou sommige waarhede op 'n ander manier geformuleer word in die hedendaagse debat, kan nie ontken word wat $V$ an der Merwe in sy artikel ook beweer nie:

In 'n tyd toe 'n breë kritiese fundamentalistiese Skrifgebruik algemeen gangbaar was in die Afrikaanse kerke en teologie (veertigerjare), stel Van Zyl 'n Skrifbeskouing wat die moderne Bybelwetenskap in 'n groot mate geantisipeer en verdiskonteer het.

Des te meer ' $n$ merkwaardige bydrae wanneer 'n mens ook bedink dat hy dit nie as Bybelwetenskaplike nie, maar eerder as sistematiese teoloog, teologiese filosoof gedoen het. Sy bydrae kan myns insiens met die volgende paar aspekte aangedui word:

- Met sy besondere Skrifbeskouing het hy gestaan in die tradisie van die NeoOrtodoksie, maar tegelyk het hy ook die kritiese studie van die Bybel aangemoedig; baie duidelik, nie kritiese studie met enige negatiewe implikasies nie, maar juis sodat alle denkbare metodes aangewend kan word om die boodskap van die Bybel te ontsluit.

- Hy het nuut en baie duidelik ook die dialektiese verhouding tussen die Bybel as boek en die Woord van God, waarom dit uiteindelik inhoudelik gaan, beklemtoon. 
- Die werking van die Heilige Gees in die verstaan en die uitleg van die Skrif het hy duidelik beklemtoon.

* Hierdie omgang met die Bybel as Woord van God kan nooit anders as dat dit die antwoord van die geloof en toewyding van die lewe opeis nie.

- Die plek van die Bybel vir die lewe van die kerk het hy baie duidelik beklemtoon, die verkondiging van hierdie Woord as die wesenlike van waaroor dit in die kerk gaan het hy baie duidelik ingesien en op elke moontlike wyse gepropageer.

- Maar ook die persoonlike geloofslewe van die lidmaat van die kerk en die afhanklikheid van hierdie geloofslewe van die Bybel het in sy nadenke baie prominent gefigureer. Daarmee saam die noodsaak dat die boodskap van die Bybel vir die lidmaat van die kerk op so 'n wyse ontsluit moet word dat die mense van die kerk nie sal ophou om Bybel te lees nie, maar daarin steeds sal groei sowel in die beoefening van Bybyl lees as in die verstaan van die boodskap van die boeke van die Bybel. 